\title{
The Identification of a Novel Peptide Derived from Lactoferrin Isolated from Camel Milk with Potential Antimicrobial Activity
}

\author{
Elnaz Khajeh $^{1}$ (D), Majid Jamshidian-Mojaver ${ }^{2 *}$ (D), Mohsen Naeemipour ${ }^{3}$, Hamidreza Farzin ${ }^{4}$
}

1. Department of Biotechcology, Sabzevar Branch, Islamic Azad University of Sabzevar, Sabzevar, Iran

2. Mashhad Branch, Razi Vaccine and Serum Research Institute, Agricultural Research, Education and Extension Organization (AREEO), Mashhad, Iran

3. Cellular and Molecular Research Center, Sabzevar University of Medical Sciences, Sabzevar, Iran

4. Mashhad Branch, Razi Vaccine and Serum Research Institute, Agricultural Research, Education and Extension Organization (AREEO), Mashhad, Iran

$\underline{10.30699 / i j m m .15 .3 .302}$

\section{ABSTRACT}

Background and Aim: Antimicrobial peptides have attracted significant attention in recent decades because of their properties, such as rapid bactericidal effects, having a wide spectrum of activity, and a rare development of drug resistance. The purpose of this study was to examine the antibacterial activity of a peptide derived from the lactoferrin isolated from camel milk against Staphylococcus aureus, Pseudomonas aeruginosa, and Acinetobacter baumannii.

Materials and Methods: In the present study, by means of bioinformatics, an antibacterial peptide was potentially identified as candidates in lactoferrin of camel milk, and an appropriate peptide was selected based on defined criteria. The PepsinCamel-Lac1 peptide was synthesized. The methyl thiazolyl diphenyl-tetrazolium bromide assay was conducted to examine the toxicity of Pepsin-Camel-Lac1 against a cell line. Three pathogenic bacteria, namely S. aureus, P. aeruginosa, and $A$. baumannii were analyzed to assess the antibacterial activity of Pepsin-Camel-Lac1 peptide.

Results: The results showed that the newly-identified peptide had no toxicity against the cell line. The minimum inhibitory concentration values of Pepsin-Camel-Lac1 against S. aureus, P. aeruginosa, and A. baumannii were $31.25 \mu \mathrm{g} / \mathrm{mL}, 31.25$ $\mu \mathrm{g} / \mathrm{mL}$, and $62.5 \mu \mathrm{g} / \mathrm{mL}$, respectively.

Conclusion: It seems that the growth of S. aureus, P. aeruginosa, and A. baumannii was not affected by Pepsin-Camel-Lac1 treatment in the bacterial culture medium.

Keywords: Milk proteins; Pepsin; Antibacterial activity; Staphylococcus aureus; Pseudomonas aeruginosa; Acinetobacter baumannii

Received: 2020/04/25; Accepted: 2021/02/24; Published Online: 2021/06/28

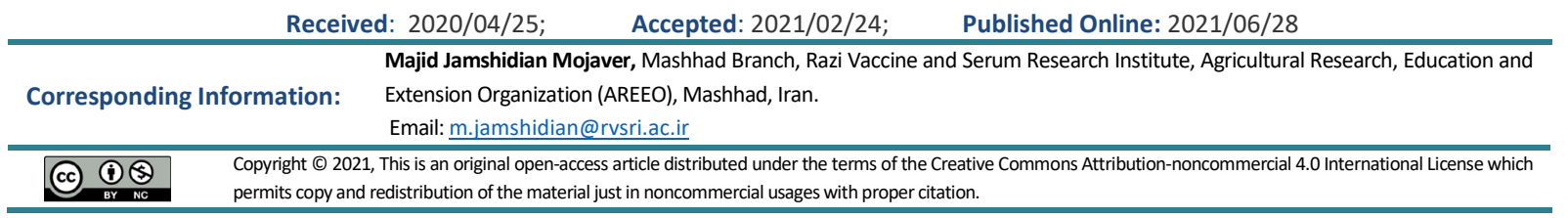

Use your device to scan and read the article online

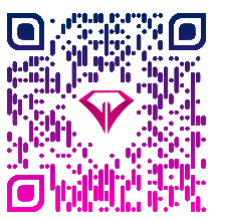

Khajeh E, Jamshidian Mojaver M, Naeemipour M, Farzin H,. The Identification of a Novel Peptide Derived from Lactoferrin Isolated from Camel Milk with Potential Antimicrobial Activity. Iran J Med Microbiol. 2021; 15 (3) 302-316.

\section{Download citation: BibTeX | RIS | EndNote | Medlars | ProCite | Reference Manager | RefWorks Send citation to: 8 Mendeley 2 zotero ${ }_{\text {RefWorks }}$}


Introduction

Milk contains a large number of proteins, some of which have been well characterized, such as lactoferrin, which exhibits antibacterial activity (1). Two iron-binding proteins, namely lactoferrin, and transferrin, have been shown to have biological activity in the milk of many species (2). The two proteins almost possess similar properties, such as molecular weight $(80 \mathrm{kDa})$ and the ability to bind to iron (3). Lactoferrin is a monomeric glycoprotein with a high affinity to iron (4). The presence of lactoferrin has been confirmed in a large number of mammals, and the amino acid sequence of this protein has been identified in human, pig, horse, camel, cattle, buffalo, goat, and mouse (5). The third structure of lactoferrin has been characterized in the five species of human, cow, buffalo, camel, and horse, all of which have the same structures (6-10). All nutrients found in human milk are also present in camel milk. A number of investigations have recently reported the therapeutic properties of camel milk, such as anti-cancer, antidiabetic, anti-microbial potential (11-14). Most secretions fluids, such as milk, saliva, tears, and neutrophil granules, contain this glycoprotein (15). In the immune system, lactoferrin is introduced as a part of the innate immune system because of its sensitive position on the mucosal surface as one of the agents existing at the first-line of defense to prevent the entry of microbial agents (16). Camel milk lactoferrin has been identified as a factor against Gram-positive and Gram-negative bacteria, as well as fungi and parasites (17). Proteins and peptides of the milk, such as lactoferrin, lactoperoxidase, and lysozyme, play an influential role in overall antimicrobial activity in milk (18). The milk proteins and peptides can be natural substitutes for antibiotics due to their antibacterial properties (19). Antimicrobial peptides (AMPs) are oligopeptides with varied numbers of amino acids (from 5 to more than 100$)(20,21)$. Some studies have analyzed the antimicrobial activity of peptides derived from lactoferrin (22-26). Camel milk lactoferrin has antibacterial activity against Escherichia coli, Salmonella typhimurium, Listeria monocytogenes, Staphylococcus aureus and Pseudomonas aeruginosa (11, 27-29). Thanks to bioinformatics tools and knowing the cleavage sites of enzymes, the identification of AMPs in natural sources, such as milk, has been feasible (30-32). Different methods are used to characterize and produce active AMPs (33). These methods are based on proteolysis using bioinformatics software and statistical analyses to assess the role of peptides released from cleaved proteins. In this study, in order to find a novel AMP, different AMPs, derived from camel milk lactoferrin, were designed by bioinformatics approaches, and then, the most appropriate AMP was chosen according to the required criteria. The designed peptide was synthesized and analyzed in terms of the antibacterial activity against P. aeruginosa, A. baumannii, and S. aureus.

\section{Materials and Methods}

\section{Bioinformatics Analysis}

\section{Selection of Effective Antimicrobial Peptide Derived from Lactoferrin}

Camel milk lactoferrin is a glycoprotein that contains 708 amino acids and possesses two domains and two iron-binding sites (34). The strategy used for AMP synthesis from camel milk lactoferrin was in accordance with bioinformatics approaches of a study conducted by Dziuba et al. (32). Based on the cleavage sites identified for various proteolytic enzymes, insilico studies indicated that pepsin is capable of releasing numerous active peptides from lactoferrin $(32,35,36)$. The initial structure of camel milk lactoferrin was obtained from the Uniport database with an ID of Q9TUM0. Next, pepsin was used to hydrolyze the protein, as this enzyme $(\mathrm{pH}>2)$ has proteolytic activity and is commonly applied to obtain bioactive peptides (37-39). Four online software tools, namely BIOPEP database, Collection of Antimicrobial Peptides Server, Antimicrobial Peptide Calculator and Predictor and Peptide cutter database were utilized to evaluate the antimicrobial properties of cleaved peptides derived from lactoferrin (40-43). The online server BIOPEP-UWM (www.uwm.edu.pl/biochemia) was utilized since it contains a library of bioactive peptides and comprises of the two essential coordinated parts, namely grouping databases and apparatuses for the assessment of proteins as the antecedents of bioactive peptides, which includes the proteolytic procedure plans. Another online database, CAMP (http://www.camp.bicnirrh. res.in), contains information about the conserved sequences, representing some examples and Hidden Markov Models (HMMs) of 1386 AMPs that are categorized into 45 families. On the other hand, the online database APD2 (http://aps.unmc.edu/AP/expectation/forecastmain.php) contains 2684 antimicrobial peptides from six kingdoms (266 from microbes, 4 from archaea, 8 from protists, 13 from parasites, 329 from plants, and 2018 from creatures) (44).

\section{Experimental Procedures}

\section{Material}

S. aureus (1074, ATCC: 6538), P. aeruginosa (1060, ATTCC: 27853), and A. baumannii (1003, ATCC: BAA747) were purchased from the Pasteur Institute of Iran.

\section{Peptide Synthesis}

The chosen peptide was named Pepsin-Camel-Lac1 (PCL1) synthesized by MIMOTOPES Pty Ltd, Australia. 
In order to prepare the designed peptide, $1 \mathrm{mg}$ of the designed peptide was dissolved in $1 \mathrm{~mL}$ of sterile water and used for the experiments.

\section{Toxicity Assay}

The Methyl thiazolyl diphenyl-tetrazolium bromide (MTT) assay was utilized to assess the toxicity of PCL1 against a human cell line. The assay is based on the decrease of the tetrazolium salt into blue formazan crystals in viable cells $(45,46)$. The cell line was cultured in the RPMI 1640 medium supplemented with $10 \%$ Fetal Bovine Serum (FBS), $100 \mathrm{ml}$ penicillin, and $100 \mathrm{mg} / \mathrm{mL}$ streptomycin. During the cell culture period, cells were incubated at $37^{\circ} \mathrm{C}$ in a $95 \%$ atmosphere and $5 \% \mathrm{CO}_{2}$. When the cells reached 80 $90 \%$ confluence, the viability of cells was examined and passaged. In this experiment, $100 \mu \mathrm{L}$ of the cell suspension was added to each well of a 96-well plate, each containing $100 \mathrm{~mL}$ of the culture medium. The cells were treated with the pre-defined concentrations of PCL-1 and then incubated for $24 \mathrm{~h}$. After dilution of PCL-1 with sterile water, cells were treated with PCL-1, and then $20 \mu \mathrm{L}$ of the MTT solution (5 $\mathrm{mg} / \mathrm{mL}$ ) was added to the wells and incubated for 24 hours. After the incubation period, $50 \mu \mathrm{L}$ of dimethyl sulfoxide (DMSO) was added to the wells to dissolve the purple formazan crystals. Afterward, according to the obtained results, the inhibitory concentration (IC50) of PCL-1 was calculated, in which $50 \%$ of the cells underwent cell death. The experiments have been carried out in triplicates, and the values were represented as the percentage of cell viability in comparison with the control cells.

\section{Preparation of Microbial Suspension Solution}

The lyophilized batches containing bacteria mentioned earlier were transferred to the liquid Mueller Hinton Broth (MHB) and incubated at $37^{\circ} \mathrm{C}$ for $24 \mathrm{~h}$. In order to determine the antimicrobial effects, a fresh 24-hour culture medium was prepared, then 1 $\mathrm{ml}$ of the $24 \mathrm{~h}$ microbial suspension was transferred into a tube containing the MHB medium, and the turbidity of the prepared microbial suspension was assessed by McFarland standards using a spectrophotometer at a wavelength of $625 \mathrm{~nm}$. The final suspension was used for the evaluation of drug susceptibility testing, MIC, and cell culture (47).

Determination of MIC and MBC Values by MicroDilution Method

The MHB medium was used to evaluate the antimicrobial effects of PCL-1 by minimum inhibitory concentration (MIC) and minimum bactericidal concentration (MBC) methods. In general, a sterile flat 96-well plate was used after determining the halfMcFarland turbidity. In this method, $50 \mathrm{~mL}$ of $\mathrm{MHB}$ medium was added to well 2 to well 11 . Then, $50 \mu \mathrm{L}$ of the PCL-1 peptide was added to well 2 to well 9 . Next, $50 \mu \mathrm{L}$ of the microbial suspension was added to well 1 well 10. Afterward, the plate was incubated for $24 \mathrm{~h}$. Well 1 that contains bacteria were considered as the negative control, while and well 11 containing the MHB medium was considered the positive controls. In order to assess the MBC values, the contents of the wells were cultured on the Mueller Hinton Agar medium. Lack of bacterial growth is indicative of MBC determination $(\mathbf{4 7}, \mathbf{4 8})$.

\section{Agar Well Diffusion Assay}

The antimicrobial activity test was performed using the Agar well diffusion assay (49). This technique is broadly used to assess antimicrobial activity. In this method, the microbial suspension is distributed on the plate surface. Then, a hole is created with a diameter of $6-8 \mathrm{~mm}$ in sterile conditions, and then specific concentrations of the PCL-1 peptide were added to the hole and left to release into the pores of Agar. Different concentrations of PCL-1 were prepared as follows; PCL-1 was transferred into 5 sterile microtubes, then $100 \mathrm{~mL}$ of sterile water was added into microtube 2 to 5 . Next, $100 \mathrm{~mL}$ of PCL-1 was added to microtube 1 and was serially transferred into other microtubes until the last microtube. After that, $100 \mu \mathrm{L}$ of the contents of each microtube was isolated and added to the plate agar. After incubating the plates at $37^{\circ} \mathrm{C}$ for $24 \mathrm{~h}$, the results were examined based on the diffused area around the created hole (47).

\section{Results}

\section{In-Silico Proteolysis of Lactoferrin}

The sequence of amino acids of lactoferrin was exposed in in-silico proteolysis performed by the BIOPEP database. In-silico proteolysis can be carried out by means of some bioinformatics tools, as we employed the peptide cutter database (https://web.expasy.org/peptide cutter/.) $(42,50)$. For insilico protein hydrolysis, a single enzyme was used and the PCL-1 peptide cleavage site was bolded (Table 1 ). The pepsin enzyme $(\mathrm{pH}>2)$ was utilized to create different peptides from lactoferrin, resulted in the production of 50 peptides with the length of 5-21 amino acids. For the statistical prediction of antimicrobial properties, the produced peptides were submitted (Table S1). A short linear peptide, PCL1, met the required criteria, as shown in Figure 1. 
Table 1. Results of peptide released from BIOEP database camel milk lactoferrin.

\begin{tabular}{|c|c|c|}
\hline Enzyme & No. of cleavages & Positions of cleavage sites \\
\hline Pepsin (pH>2) & 188 & $\begin{array}{c}23589101113141516171827404162777881828384879092100101110111122 \\
123124125127128130131138143144149150153155156157163170171188190191 \\
207209210211214215217226227233234237246247248265266285286287288289 \\
296297304305306307308316318319323324325326327336337338339342343349 \\
358359365366374375379380401402403404410411412413416417418419430441 \\
442451453467469470485486492494502504505506520522523542544545548549 \\
551560561567568578579582584585587588589590591592593608625626629630 \\
631636637647648650651657659660666667669670676678679684690691698700 \\
704705706\end{array}$ \\
\hline
\end{tabular}

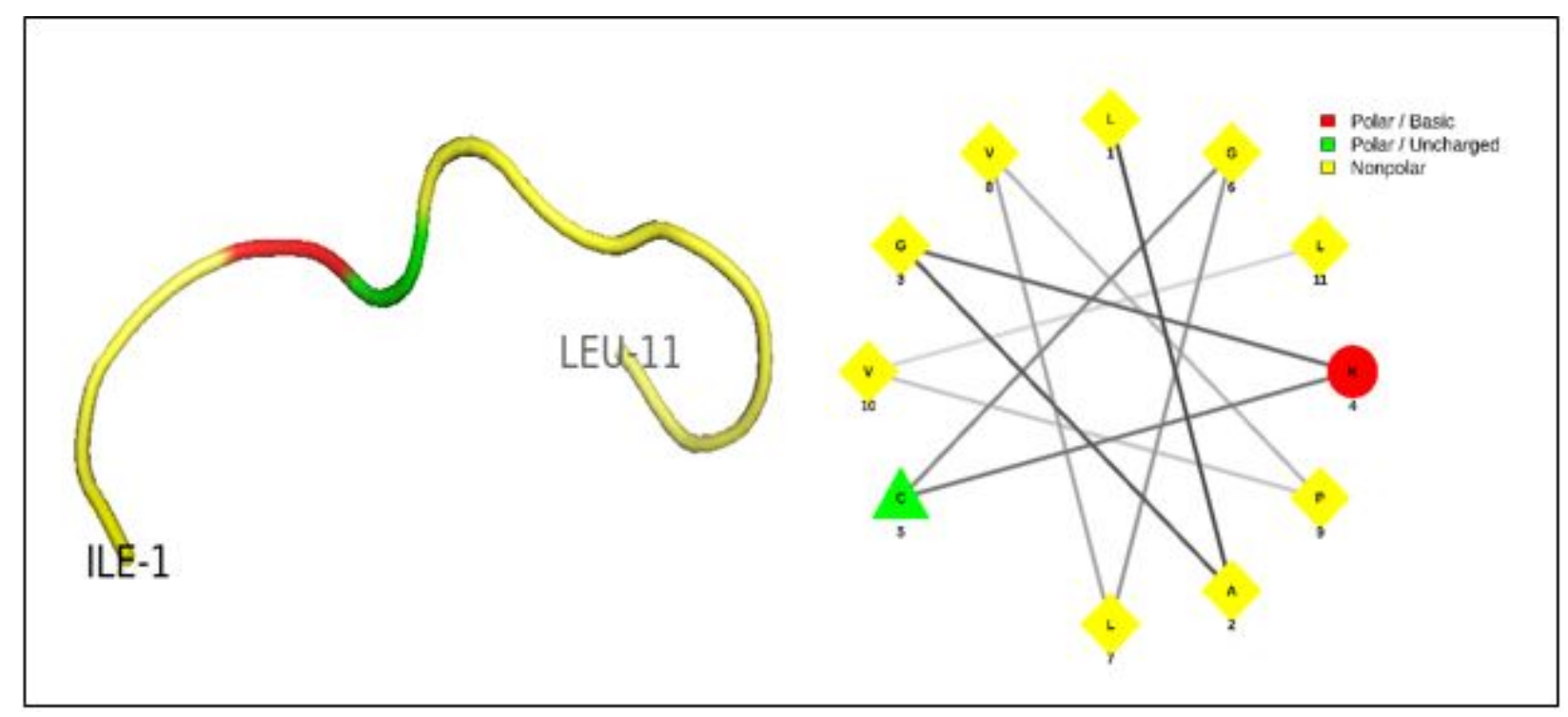

Figure 1. The PCL1 peptide picture consisted of 11 amino acids and has a liner structure.

\section{Physicochemical Properties of AMPs}

The physicochemical properties of antimicrobial peptides designed by the BIOPEP database were characterized using free web tools and the algorithms for the chosen AMP are shown (Table S1). The molecular weights of created peptides were in a range of 446 to $2493 \mathrm{Da}$ (Table S1). Among 50 peptides created, 26 peptides had a pl value of less than 7, while the rest has above 7 . It is now known that the molecular charge and hydrophobicity play a significant role in the functionality of AMPs (51-53). Among 50 peptides derived from lactoferrin, 14 peptides had a negative charge, 25 possess a positive charge, and 11 were neutral. In the present study, only positive AMPs were selected for further analyses. Because cationic peptides constitute a significant percentage of AMPs, as a result of their higher affinity to bind to negatively charged cell membranes of bacteria and eventually disrupt the bilayer lipid structure $(54,55)$. Amphipathic property is another marked parameter to choose efficient AMPs since these structures allow them to bind to hydrophilic regions; hence AMPs with both hydrophilic and hydrophobic domains have a higher priority to be used for antibacterial tests (56). The amino acid composition also plays a role in designing the antibacterial peptides. Gram-positive and Gram-negative antimicrobial peptides have a similar ratio of cysteine and lysine residues (57). As shown in Table 1, the PCL1 peptide composed of $63 \%$ hydrophobic region, $27 \%$ hydrophilic region, and $9 \%$ charged amino acids; Also, it contains $18 \%$ lysine and $9 \%$ cysteine.

Table 2. Physical and chemical characteristics of the Pepsin-Camel-Lac1 peptide.

\begin{tabular}{|ccccccc}
$\begin{array}{c}\text { Position of cleavage } \\
\text { site }\end{array}$ & Enzyme & Peptide sequence & $\begin{array}{c}\text { Peptide length } \\
\text { [aa] }\end{array}$ & $\begin{array}{c}\text { Peptide mass } \\
\text { [Da] }\end{array}$ & Seq. ID & Charge \\
\hline 430 & $\begin{array}{c}\text { Pepsin } \\
(\mathrm{pH}>2)\end{array}$ & $\begin{array}{c}>30 \\
\text { IAGKCGLVPVL }\end{array}$ & 11 & 1069.371 & 30 & 8.22 \\
\hline
\end{tabular}


306 The Identification of a Novel Peptide Derived from...

Table S 1. Physical and chemical characteristics of the synthesized peptides.

\begin{tabular}{|c|c|c|c|c|c|c|c|}
\hline Sequence ID & $\begin{array}{l}\text { Name of } \\
\text { cleaving } \\
\text { enzyme(s) }\end{array}$ & Resulting peptide sequence & $\begin{array}{c}\text { Peptide } \\
\text { length [aa] }\end{array}$ & $\begin{array}{l}\text { Peptide } \\
\text { mass [Da] }\end{array}$ & $\begin{array}{c}\text { Position of } \\
\text { cleavage } \\
\text { site }\end{array}$ & pl & Charge \\
\hline 1 & $\begin{array}{l}\text { Pepsin } \\
(\mathrm{pH}>2)\end{array}$ & >1 AASKKSVRW & 9 & 1032.211 & 27 & 11.12 & +3 \\
\hline 2 & $\begin{array}{l}\text { Pepsin } \\
(\mathrm{pH}>2)\end{array}$ & >2 CTTSPAESSKCAQ & 13 & 1312.432 & 40 & 6.25 & 0 \\
\hline 3 & $\begin{array}{l}\text { Pepsin } \\
(\mathrm{pH}>2)\end{array}$ & >3 QRRMKKVRGPSVTCVKKTSRF & 21 & 2493.033 & 62 & 12.2 & +8 \\
\hline 4 & $\begin{array}{l}\text { Pepsin } \\
(\mathrm{pH}>2)\end{array}$ & >4 ECIQAISTEKADAVT & 15 & 1578.755 & 77 & 4.14 & -2 \\
\hline 5 & $\begin{array}{l}\text { Pepsin } \\
(\mathrm{pH}>2)\end{array}$ & $>5$ LRPIAAEV & 8 & 868.044 & 100 & 6.25 & 0 \\
\hline 6 & $\begin{array}{l}\text { Pepsin } \\
(\mathrm{pH}>2)\end{array}$ & >6 GTENNPQTH & 9 & 996.989 & 110 & 5.5 & -1 \\
\hline 7 & $\begin{array}{l}\text { Pepsin } \\
(\mathrm{pH}>2)\end{array}$ & >7 YAVAIAKKGTN & 11 & 1135.329 & 122 & 9.72 & +2 \\
\hline 8 & $\begin{array}{l}\text { Pepsin } \\
(\mathrm{pH}>2)\end{array}$ & $>8 \mathrm{KSCHTGL}$ & 7 & 744.864 & 138 & 8.22 & +1 \\
\hline 9 & $\begin{array}{l}\text { Pepsin } \\
(\mathrm{pH}>2)\end{array}$ & $>9$ GRSAG & 5 & 446.464 & 143 & 10 & +1 \\
\hline 10 & $\begin{array}{l}\text { Pepsin } \\
(\mathrm{pH}>2)\end{array}$ & $>10$ NIPMG & 5 & 530.640 & 149 & 5.5 & 0 \\
\hline 11 & $\begin{array}{l}\text { Pepsin } \\
(\mathrm{pH}>2)\end{array}$ & >11 TGPPEP & 6 & 596.638 & 163 & 3.81 & -1 \\
\hline 12 & $\begin{array}{l}\text { Pepsin } \\
(\mathrm{pH}>2)\end{array}$ & >12 LQKAVAK & 7 & 756.944 & 170 & 10 & +2 \\
\hline 13 & $\begin{array}{l}\text { Pepsin } \\
(\mathrm{pH}>2)\end{array}$ & >13 FSASCVPCVDGKEYPNL & 17 & 1829.073 & 188 & 4.47 & -1 \\
\hline 14 & $\begin{array}{l}\text { Pepsin } \\
(\mathrm{pH}>2)\end{array}$ & >14 CAGTGENKCACSSQEP & 16 & 1584.711 & 207 & 10 & -1 \\
\hline 15 & $\begin{array}{l}\text { Pepsin } \\
(\mathrm{pH}>2)\end{array}$ & >15 LQDGAGDVA & 9 & 844.877 & 226 & 3.53 & -2 \\
\hline 16 & $\begin{array}{l}\text { Pepsin } \\
(\mathrm{pH}>2)\end{array}$ & >16 VKDSTV & 6 & 647.726 & 233 & 6.25 & 0 \\
\hline 17 & $\begin{array}{l}\text { Pepsin } \\
(\mathrm{pH}>2)\end{array}$ & >17 PAKADRDQY & 9 & 1063.135 & 246 & 6.25 & 0 \\
\hline 18 & $\begin{array}{l}\text { Pepsin } \\
(\mathrm{pH}>2)\end{array}$ & >18 LCPNNTRKPVDASQECH & 17 & 1912.125 & 265 & 7.09 & 0 \\
\hline 19 & $\begin{array}{l}\text { Pepsin } \\
(\mathrm{pH}>2)\end{array}$ & >19 ARVPSHAVVARSVNGKEDL & 19 & 2005.265 & 285 & 9.06 & +1 \\
\hline 20 & $\begin{array}{l}\text { Pepsin } \\
(\mathrm{pH}>2)\end{array}$ & >20 LVKAQEK & 7 & 814.980 & 296 & 8.88 & +1 \\
\hline 21 & $\begin{array}{l}\text { Pepsin } \\
(\mathrm{pH}>2)\end{array}$ & >21 GRGKPSA & 7 & 671.754 & 304 & 11.12 & +2 \\
\hline 22 & $\begin{array}{l}\text { Pepsin } \\
(\mathrm{pH}>2)\end{array}$ & >22 GSPAGQKD & 8 & 758.786 & 316 & 6.25 & 0 \\
\hline 23 & $\begin{array}{l}\text { Pepsin } \\
(\mathrm{pH}>2)\end{array}$ & >23 RIPSKIDSG & 9 & 972.109 & 336 & 8.88 & +1 \\
\hline 24 & $\begin{array}{l}\text { Pepsin } \\
(\mathrm{pH}>2)\end{array}$ & $>24$ ITAIRG & 6 & 629.757 & 349 & 10 & +1 \\
\hline 25 & $\begin{array}{l}\text { Pepsin } \\
(\mathrm{pH}>2)\end{array}$ & >25 LRETAAEVE & 9 & 1017.104 & 358 & 4.14 & -2 \\
\hline 26 & $\begin{array}{l}\text { Pepsin } \\
(\mathrm{pH}>2)\end{array}$ & >26 RRAQVV & 6 & 727.865 & 365 & 11.97 & +2 \\
\hline 27 & $\begin{array}{l}\text { Pepsin } \\
(\mathrm{pH}>2)\end{array}$ & >27 RRAQVV & 8 & 807.830 & 374 & 11.97 & +2 \\
\hline 28 & $\begin{array}{l}\text { Pepsin } \\
(\mathrm{pH}>2)\end{array}$ & >28 SRQSNQSVVCATASTTEDCIA & 21 & 2171.339 & 401 & 4.47 & -1 \\
\hline 29 & $\begin{array}{l}\text { Pepsin } \\
(\mathrm{pH}>2)\end{array}$ & $>29$ KGEADA & 6 & 589.603 & 410 & 4.47 & -1 \\
\hline 30 & $\begin{array}{l}\text { Pepsin } \\
(\mathrm{pH}>2)\end{array}$ & >30 IAGKCGLVPVL & 11 & 1069.371 & 430 & 8.22 & +1 \\
\hline 31 & $\begin{array}{l}\text { Pepsin } \\
(\mathrm{pH}>2)\end{array}$ & >31 AESQQSPESSG & 11 & 1106.068 & 441 & 3.53 & -2 \\
\hline 32 & $\begin{array}{l}\text { Pepsin } \\
(\mathrm{pH}>2)\end{array}$ & >32 DCVHRPVKG & 9 & 1010.179 & 451 & 8.22 & +1 \\
\hline
\end{tabular}




\begin{tabular}{|c|c|c|c|c|c|c|c|}
\hline Sequence ID & $\begin{array}{l}\text { Name of } \\
\text { cleaving } \\
\text { enzyme(s) }\end{array}$ & Resulting peptide sequence & $\begin{array}{c}\text { Peptide } \\
\text { length [aa] }\end{array}$ & $\begin{array}{l}\text { Peptide } \\
\text { mass [Da] }\end{array}$ & $\begin{array}{c}\text { Position of } \\
\text { cleavage } \\
\text { site }\end{array}$ & pl & Charge \\
\hline 33 & $\begin{array}{l}\text { Pepsin } \\
(\mathrm{pH}>2)\end{array}$ & >33 AVAVVRKANDKITW & 14 & 1570.855 & 467 & 10 & +2 \\
\hline 34 & $\begin{array}{l}\text { Pepsin } \\
(\mathrm{pH}>2)\end{array}$ & >34 RGKKSCHTAVDRTAG & 15 & 1586.789 & 485 & 10 & +3 \\
\hline 35 & $\begin{array}{l}\text { Pepsin } \\
(\mathrm{pH}>2)\end{array}$ & >35 NIPMGP & 6 & 627.756 & 492 & 5.5 & 0 \\
\hline 36 & $\begin{array}{l}\text { Pepsin } \\
(\mathrm{pH}>2)\end{array}$ & >36 KNTDSCRF & 8 & 970.068 & 502 & 8.22 & +1 \\
\hline 37 & $\begin{array}{l}\text { Pepsin } \\
(\mathrm{pH}>2)\end{array}$ & >37 SQSCAPGSDPRSKL & 14 & 1432.571 & 520 & 8.22 & +1 \\
\hline 38 & $\begin{array}{l}\text { Pepsin } \\
(\mathrm{pH}>2)\end{array}$ & >38 CAGNEEGQNKCVPNSSERY & 19 & 2085.207 & 542 & 4.7 & -1 \\
\hline 39 & $\begin{array}{l}\text { Pepsin } \\
(\mathrm{pH}>2)\end{array}$ & >39 LAENVGDVA & 9 & 886.957 & 560 & 3.53 & -2 \\
\hline 40 & $\begin{array}{l}\text { Pepsin } \\
(\mathrm{pH}>2)\end{array}$ & $>40$ VKDVTV & 6 & 659.781 & 567 & 6.25 & 0 \\
\hline 41 & $\begin{array}{l}\text { Pepsin } \\
(\mathrm{pH}>2)\end{array}$ & >41 DNTDGKNTEQ & 10 & 1121.082 & 578 & 4.14 & -2 \\
\hline 42 & $\begin{array}{l}\text { Pepsin } \\
(\mathrm{pH}>2)\end{array}$ & >42 NGTRKPVTEAESCHL & 15 & 1641.819 & 608 & 7.19 & 0 \\
\hline 43 & $\begin{array}{l}\text { Pepsin } \\
(\mathrm{pH}>2)\end{array}$ & $>43$ PVAPNHAVVSRIDKVAH & 17 & 1810.089 & 625 & 9.06 & +1 \\
\hline 44 & $\begin{array}{l}\text { Pepsin } \\
(\mathrm{pH}>2)\end{array}$ & >44 GRNGQDCPGK & 10 & 1031.111 & 647 & 8.22 & +1 \\
\hline 45 & $\begin{array}{l}\text { Pepsin } \\
(\mathrm{pH}>2)\end{array}$ & $>45$ QSKTKN & 6 & 704.781 & 657 & 10 & +2 \\
\hline 46 & $\begin{array}{l}\text { Pepsin } \\
(\mathrm{pH}>2)\end{array}$ & $>46$ NDNTEC & 6 & 694.671 & 666 & 3.53 & -2 \\
\hline 47 & $\begin{array}{l}\text { Pepsin } \\
(\mathrm{pH}>2)\end{array}$ & >47 QGKTTY & 6 & 696.758 & 676 & 8.88 & +1 \\
\hline 48 & $\begin{array}{l}\text { Pepsin } \\
(\mathrm{pH}>2)\end{array}$ & $>48$ LGPQY & 5 & 576.650 & 684 & 5.5 & 0 \\
\hline 49 & $\begin{array}{l}\text { Pepsin } \\
(\mathrm{pH}>2)\end{array}$ & $>49$ VTAIAK & 6 & 601.744 & 690 & 8.88 & +1 \\
\hline 50 & $\begin{array}{l}\text { Pepsin } \\
(\mathrm{pH}>2)\end{array}$ & >50 RRCSTSP & 7 & 805.907 & 698 & 10 & +2 \\
\hline
\end{tabular}

Table S 2. Predict Antimicrobial Peptides.

\begin{tabular}{|c|c|c|c|c|c|c|c|}
\hline \multirow[b]{2}{*}{ Seq. ID. } & \multicolumn{2}{|c|}{$\begin{array}{l}\text { Results with Support Vector } \\
\text { Machine (SVM) classifier }\end{array}$} & \multicolumn{2}{|c|}{$\begin{array}{c}\text { Results with Random Forest } \\
\text { Classifier }\end{array}$} & \multirow{2}{*}{$\begin{array}{l}\text { Results with Artificial } \\
\text { Neural Network (ANN) } \\
\text { classifier } \\
\text { Class }\end{array}$} & \multicolumn{2}{|c|}{$\begin{array}{l}\text { Results with Discriminant } \\
\text { Analysis classifier }\end{array}$} \\
\hline & Class & AMP Probability & Class & AMP Probability & & Class & AMP Probability \\
\hline 1 & AMP & 0.941 & AMP & 0.584 & AMP & NAMP & 0.094 \\
\hline 2 & NAMP & 0.016 & NAMP & 0.3475 & NAMP & NAMP & 0.029 \\
\hline 3 & NAMP & 0.038 & AMP & 0.6 & NAMP & NAMP & 0.421 \\
\hline 4 & NAMP & 0.095 & NAMP & 0.2235 & NAMP & NAMP & 0.004 \\
\hline 5 & NAMP & 0.004 & NAMP & 0.331 & NAMP & NAMP & 0.003 \\
\hline 6 & NAMP & 0.138 & AMP & 0.603 & NAMP & NAMP & 0.004 \\
\hline 7 & AMP & 0.595 & NAMP & 0.215 & AMP & AMP & 0.522 \\
\hline 8 & AMP & 0.714 & NAMP & 0.332 & NAMP & NAMP & 0.024 \\
\hline 9 & NAMP & 0.000 & NAMP & 0.289 & NAMP & NAMP & 0.000 \\
\hline 10 & NAMP & 0.002 & NAMP & 0.347 & AMP & NAMP & 0.001 \\
\hline 11 & AMP & 0.996 & AMP & 0.691 & NAMP & NAMP & 0.000 \\
\hline 12 & NAMP & 0.239 & NAMP & 0.374 & AMP & NAMP & 0.147 \\
\hline 13 & NAMP & 0.144 & NAMP & 0.145 & NAMP & NAMP & 0.033 \\
\hline 14 & NAMP & 0.230 & NAMP & 0.298 & NAMP & NAMP & 0.056 \\
\hline
\end{tabular}




\begin{tabular}{|c|c|c|c|c|c|c|c|}
\hline \multirow[b]{2}{*}{15} & \multicolumn{2}{|c|}{$\begin{array}{l}\text { Results with Support Vector } \\
\text { Machine (SVM) classifier }\end{array}$} & \multicolumn{2}{|c|}{$\begin{array}{c}\text { Results with Random Forest } \\
\text { Classifier }\end{array}$} & \multirow{2}{*}{$\begin{array}{l}\text { Results with Artificial } \\
\text { Neural Network (ANN) } \\
\text { classifier } \\
\text { NAMP }\end{array}$} & \multicolumn{2}{|c|}{$\begin{array}{l}\text { Results with Discriminant } \\
\text { Analysis classifier }\end{array}$} \\
\hline & AMP & 0.929 & NAMP & 0.354 & & NAMP & 0.001 \\
\hline 16 & NAMP & 0.008 & NAMP & 0.347 & NAMP & NAMP & 0.000 \\
\hline 17 & NAMP & 0.011 & AMP & 0.5275 & NAMP & NAMP & 0.001 \\
\hline 18 & NAMP & 0.063 & NAMP & 0.083 & NAMP & NAMP & 0.004 \\
\hline 19 & NAMP & 0.345 & NAMP & 0.17 & NAMP & NAMP & 0.036 \\
\hline 20 & NAMP & 0.002 & NAMP & 0.297 & NAMP & NAMP & 0.004 \\
\hline 21 & NAMP & 0.001 & NAMP & 0.3515 & NAMP & NAMP & 0.001 \\
\hline 22 & NAMP & 0.000 & NAMP & 0.3385 & NAMP & NAMP & 0.000 \\
\hline 23 & NAMP & 0.093 & NAMP & 0.265 & NAMP & NAMP & 0.009 \\
\hline 24 & NAMP & 0.000 & NAMP & 0.4965 & AMP & NAMP & 0.263 \\
\hline 25 & NAMP & 0.001 & NAMP & 0.2205 & NAMP & NAMP & 0.000 \\
\hline 26 & NAMP & 0.008 & NAMP & 0.455 & NAMP & NAMP & 0.019 \\
\hline 27 & NAMP & 0.025 & NAMP & 0.378 & NAMP & NAMP & 0.000 \\
\hline 28 & NAMP & 0.033 & NAMP & 0.1255 & NAMP & NAMP & 0.002 \\
\hline 29 & NAMP & 0.216 & NAMP & 0.455 & NAMP & NAMP & 0.000 \\
\hline 30 & NAMP & 0.146 & AMP & 0.5805 & AMP & AMP & 0.949 \\
\hline 31 & NAMP & 0.387 & NAMP & 0.364 & NAMP & NAMP & 0.000 \\
\hline 32 & NAMP & 0.003 & NAMP & 0.3025 & AMP & NAMP & 0.000 \\
\hline 33 & NAMP & 0.399 & AMP & 0.567 & AMP & NAMP & 0.326 \\
\hline 34 & NAMP & 0.188 & NAMP & 0.186 & NAMP & NAMP & 0.003 \\
\hline 35 & NAMP & 0.005 & NAMP & 0.4345 & AMP & NAMP & 0.003 \\
\hline 36 & NAMP & 0.004 & NAMP & 0.3385 & NAMP & NAMP & 0.187 \\
\hline 37 & NAMP & 0.008 & NAMP & 0.1685 & NAMP & NAMP & 0.003 \\
\hline 38 & NAMP & 0.178 & NAMP & 0.2445 & NAMP & NAMP & 0.039 \\
\hline 39 & AMP & 0.593 & NAMP & 0.3495 & NAMP & NAMP & 0.001 \\
\hline 40 & NAMP & 0.007 & NAMP & 0.443 & NAMP & NAMP & 0.000 \\
\hline 41 & NAMP & 0.026 & AMP & 0.627 & NAMP & NAMP & 0.000 \\
\hline 42 & NAMP & 0.060 & NAMP & 0.0225 & NAMP & NAMP & 0.001 \\
\hline 43 & NAMP & 0.256 & NAMP & 0.0655 & NAMP & NAMP & 0.014 \\
\hline 44 & NAMP & 0.002 & NAMP & 0.2105 & NAMP & NAMP & 0.001 \\
\hline 45 & AMP & 0.999 & AMP & 0.501 & AMP & NAMP & 0.063 \\
\hline 46 & AMP & 0.984 & NAMP & 0.336 & NAMP & NAMP & 0.017 \\
\hline 47 & AMP & 0.760 & NAMP & 0.3345 & NAMP & NAMP & 0.002 \\
\hline 48 & NAMP & 0.052 & NAMP & 0.294 & AMP & NAMP & 0.041 \\
\hline 49 & NAMP & 0.000 & AMP & 0.503 & AMP & NAMP & 0.169 \\
\hline 50 & AMP & 0.999 & NAMP & 0.4025 & NAMP & NAMP & 0.086 \\
\hline
\end{tabular}


Prediction of the Antimicrobial Activity of Produced Peptides During In-Silico Proteolysis from Lactoferrin

The in-silico proteolysis of lactoferrin leads to the generation of short peptides. Among the created peptides, the PCL-1 peptide shows anti-bacterial, antiviral, and anti-tumor activity due to its high positive charge and ability to interact with negatively charged substrates, such as glycosaminoglycan, lipopolysaccharide, heparan, phosphatidylserine, and nucleic acids $(58,59)$. The design of peptides varies depending on the biological activity of these macromolecules
(22). Many peptides have a wide range of activity, such as the antibacterial and anti-cancer properties (60). For example, the design of AMPs derived from the lactoferrin protein has been conducted using the CAMP tools. To this aim, Four software tools have been employed, namely Random Forest, Support Vector Machines, Artificial Neural Network, and Discriminant Analysis (41). In this analysis, the resultant score was in excess of 0.45 ; therefore, the PCL1 peptide was listed as AMPs, and a positive classification was obtained for at least two statistical methods (Table 3 ).

Table 3. The characteristics of PCL1 peptide released during in-silico proteolysis and prediction.

\begin{tabular}{|ccccccccc}
\hline & \multicolumn{2}{c}{ SVM classifier } & \multicolumn{2}{c}{ RF Classifier } & \multicolumn{2}{c}{ ANN classifier } \\
\hline Sequence & Class & $\begin{array}{c}\text { AMP } \\
\text { Probability }\end{array}$ & Class & $\begin{array}{c}\text { AMP } \\
\text { Probability }\end{array}$ & Class & Class & Probability \\
\hline IAGKCGLVPL & NAMP & 0.146 & AMP & 0.5805 & AMP & AMP \\
\hline
\end{tabular}

Four statistical models in the CAMP database: SVM, RF, ANN and DA classiers that used for proteolysis and prediction peptides.

\section{Toxicity Assay}

In order to achieve a linear regression equation of the concentrations of PCL-1 versus the growth inhibition, Microsoft Excel software was used, and the values were expressed as the means and standard deviation of the means of three separate experiments. The below equation was used to measure the growth curve and draw a plot:

Growth inhibition $=($ control OD-sample OD $) /$ control OD*100 (61)
Finally, the IC50 values of specimens, representing a concentration of the peptide by which $50 \%$ of bacteria are eliminated, were obtained from the growth curve. The SPSS software version 16 was used for the analysis of the obtained data, and the difference between various treatments was analyzed by one-way analysis of variance (one-way ANOVA) followed by Tukey's post hoc test (Table 4). The MTT results showed that PCL-1 has no significant effect on the viability of the cell line used (Figure 2).

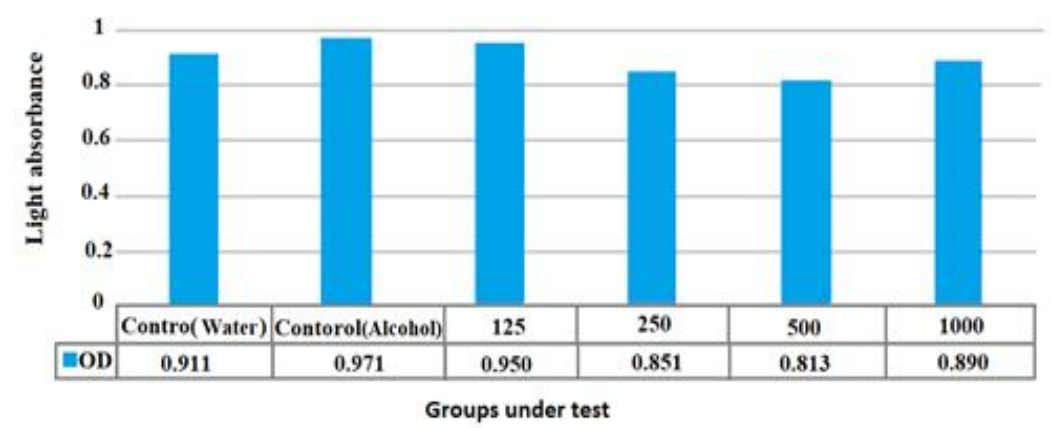

Figure 2. MTT cell line with PCL1 peptide with sig= 0.00

Table 4. Results of analysis using SPSS technology of mixed PCL1 peptide levels on cell lines

\begin{tabular}{|ccccc} 
& Sum of Squares & df & Mean Square & Sig \\
\hline Between Groups & 1.500 & 5 & 0.3 & 0.001 \\
\hline Within Groups & 0.424 & 12 & 0.035 \\
\hline Total & 1.924 & 17 & \\
\hline
\end{tabular}


Determination of MIC and MBC Values by MicroDilution Method

The MIC values of bacterial strains were calculated by the micro-dilution method. After two hours of incubation, the turbidity of samples was read at wavelengths of 490 and $630 \mathrm{~nm}$ using an ELISA reader. The well in which bacterial growth inhibition occurred was regarded as the MIC values and used to determine the $\mathrm{MBC}$ value. Following the incubation period, the first dilution in which bacteria did not grow on the agar plate was regarded as the $\mathrm{MBC}$ value. According to Figure 3, the MIC values for $S$. aureus in response to PCL-1 was reported to be $31.25 \mu \mathrm{g} / \mathrm{mL}$, while the $\mathrm{MBC}$ value was $500 \mu \mathrm{g} / \mathrm{mL}$ (Figure $3 \mathrm{~A}$ ).

The MIC and MBC values for $P$. aeruginosa were $31.25 \mu \mathrm{g} / \mathrm{mL}$ and $125 \mu \mathrm{g} / \mathrm{mL}$, respectively (Figure $3 B$ ). In addition, the values of MIC and MBC for $A$. baumannii were $62.5 \mu \mathrm{g} / \mathrm{mL}$ and $500 \mu \mathrm{g} / \mathrm{mL}$, respectively (Figure $3 \mathrm{C}$ ).
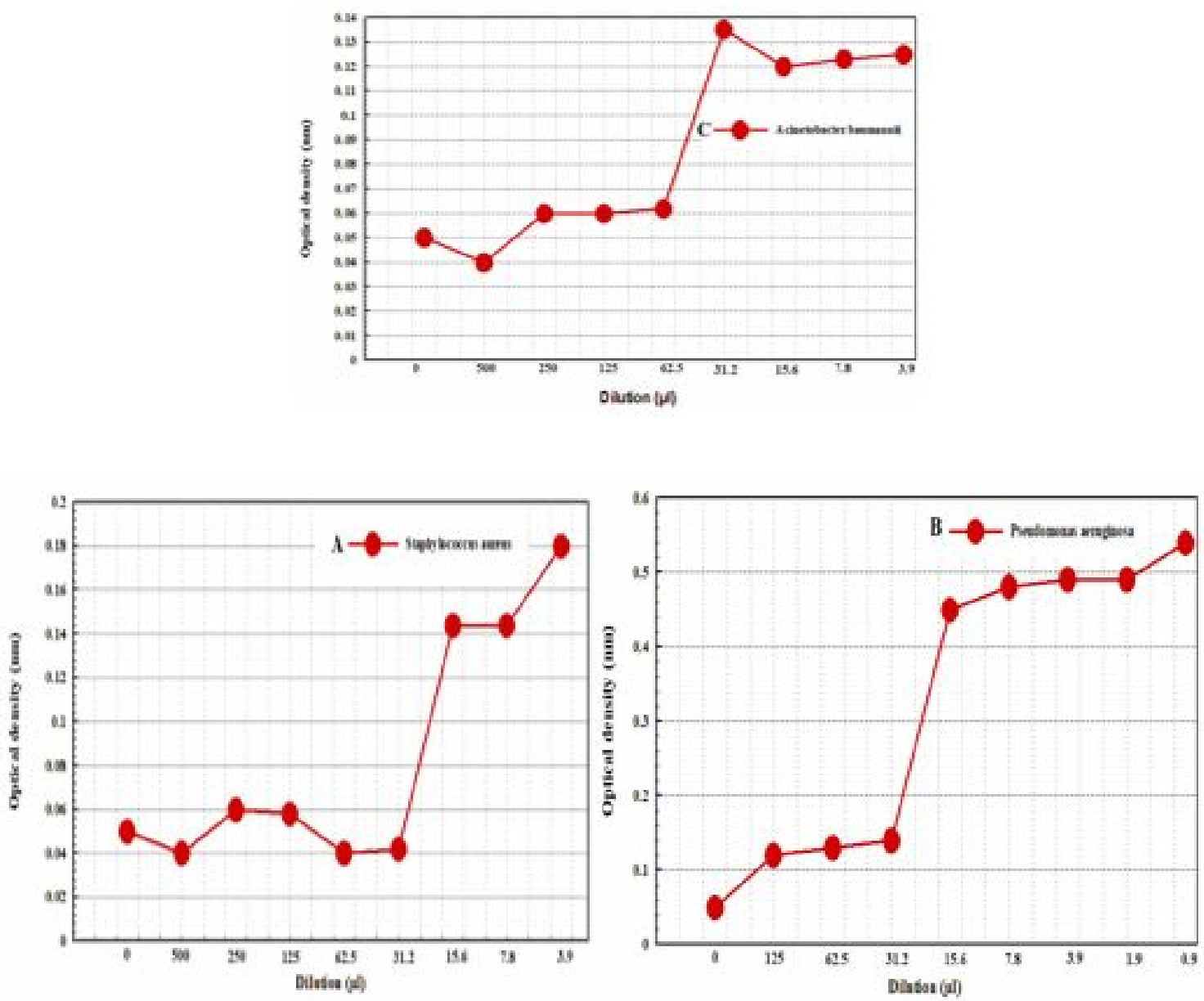

Figure 3. MIC and MBC analyze outcomes for the three bacterial strains that were tested in A, B, and C for S.Aureus, P.Aeruginosa, and A.Baumannii.

\section{Agar Well Diffusion Assay}

The diameter created around the holes in agar indicates the effect of PCL-1 on the inhibition growth of bacterial strains. The results demonstrated that PCL-1 had no significant effect on the growth inhibition of the three bacterial strains when compared with the control group (Figure 4). 

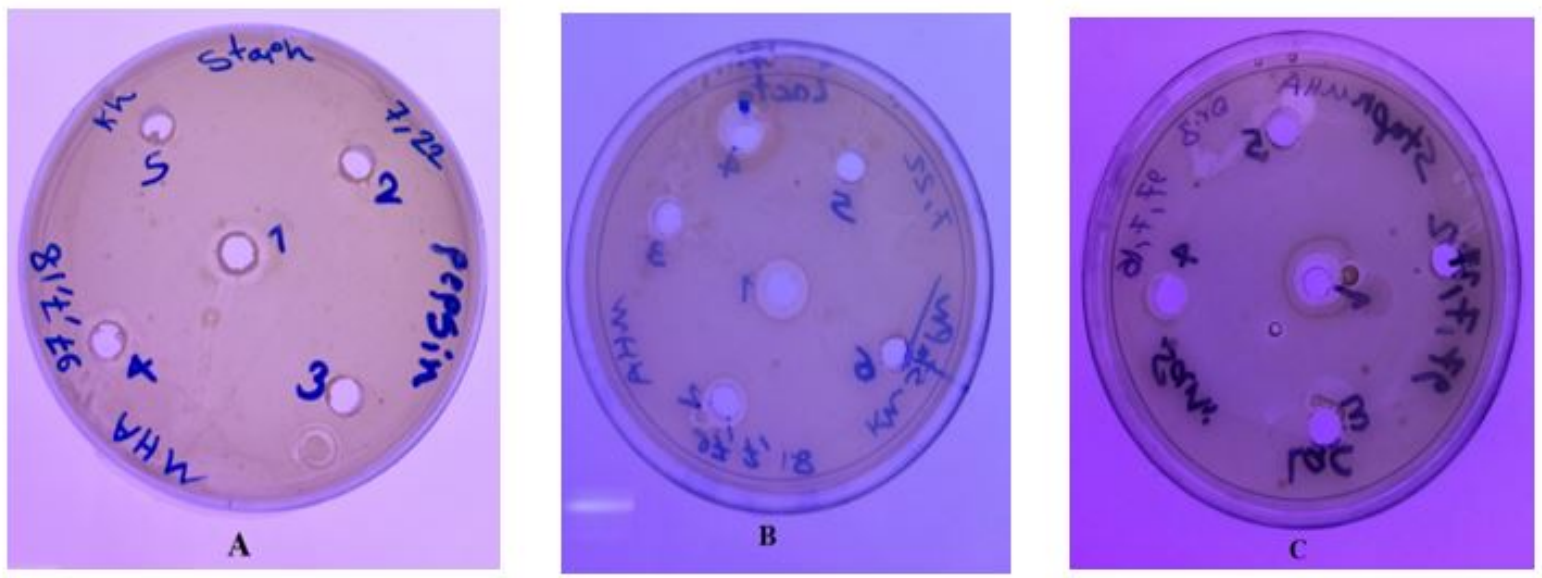

Figure 4. Results of agar well diffusion assay for Staphylococcus Aureus, Pseudomonas Aeruginosa, and Acinetobacter Baumannii are respectively in $A, B$, and $C$.

\section{Discussion}

In an in-silico proteolysis conducted by Dziuba et al., 11 new peptides with potential antimicrobial activity were picked from all the digested peptides in the milk protein (32). Jahani et al. demonstrated that lactoferrin to be effective as an antibacterial against Gram-positive (Staphylococcus epidermidis, Bacillus cereus) and Gram-negative (Campylobacter jejuni, Salmonella spp.) bacteria. However, it was more effective on the Gram-positive instead of the Gramnegative bacteria (62). In line with the investigation of peptides derived from milk lactoferrin through the milk fermentation and assessment of their antibacterial effects, Korheonan et al. reported that milk proteins contain a rich source of peptides that could be potentially released and activated. For example, when these peptides are activated during gastricintestinal digestion or milk fermentation, they could be involved in modulatory processes in living systems (33). Bushra Niaz et al. reported that due to the association of lactoferrin with enterobacterial lipopolysaccharide (LPS), it acts as a permeabilizing agent of Gram-negative bacteria and destabilizes the bacterial membrane and thus enhance bacterial permeability. Lactoferrin is not an effective antibacterial agent of its own, but allows those peptides that have been derived from it, whose hydrophobicity impose a limit on their effectiveness, to enter the bacterial membrane as an antibacterial agent.(63). As a result of direct interaction between protein or lactoferrin-derived peptides, Farnaud and Evans identified that it possesses bactericidal activities (25). Cameleers believe that camel milk is more resistant to spoilage than the milk of other animals, and it has a longer shelf life. The effect of lactoperoxidase can be one of the significant factors leading to camel milk resistance to spoilage. In this work, antimicrobial peptides were identified from camel milk lactoferrin using bioinformatics; then, the PCL-1 peptide was selected, and the activity of this peptide was evaluated in-vitro. In the first step, the hydrolysis of lactoferrin was performed using the pepsin enzyme using the BIOPEP database by which 50 peptides were produced containing 5-21 amino acids. The physicochemical properties of the synthesized peptides were investigated using online tools, such as the APD2 and Peptide cutter databases, to select appropriate AMPs. The general properties of the generated peptides, including molecular weight, charge, and PI values, were analyzed to select the appropriate antimicrobial peptides (Table S1). Among the created peptides, two peptides met the initial criteria, but since the presence of lysine and cysteine amino acids in AMPs is an advantage, the peptide with an ID of 30 (PCL-1 peptide) was selected for further analyses (Table 1). Four tools of the CAMP database (ANN, DA, RF, SVM) were employed to determine the antibacterial activity of the created peptides in this study. The PCL-1 peptide was classified as AMPs since it had parameters with scores of higher than 0.45, including RF: 0.5805 and DA: 0.949 (Table 3). After synthesizing the PCL-1 peptide, the viability of bacteria in response to PCL-1, MBC, MIC, agar well diffusion was assessed in order to determine the antimicrobial activity, as well as toxicity against the human cell line. The MTT assay showed that this peptide had no toxicity against the human cell line. Our findings also showed the MIC and MBC values for $S$. aureus, $P$. aeruginosa, and $A$. baumannii were 31.25/500, $21.25 / 125$, and $62.5 / 500$, respectively. The agar well diffusion assay showed that the analyzed bacteria were resistant to the PCL-1 peptide. The experimental results of this study showed that the PCL-1 peptide had no antimicrobial properties. 


\section{Conclusion}

There are naturally occurring bioactive peptides in fermented dairy products, such as yogurt, butter, milk, and cheese, which are inactivated in primary sources, and they could be activated by digestion of milk, milk fermentation, exposure to proteolytic starter media, or hydrolysis using proteolytic enzymes. Milk-derived peptides exhibit super-beneficial activity, even through oral consumption. In this study, pepsindigested peptides in milk lactoferrin were identified by bioinformatics tools. After the synthesis of PCL-1, the MTT assay was applied to assess the toxicity of the selected peptide against the human cell line. The results showed that the chosen peptide had no toxicity against the human cell line or bacterial strains.

\section{Abbreviations}

Antimicrobial peptides: AMPs, Collection of Antimicrobial Peptides: CAMP, Antimicrobial Peptide Calculator and Predictor: APD2, Pepsin-Camel-Lac1: PCL1, Methyl thiazolyl diphenyl-tetrazolium bromide: MTT, Mueller Hinton Broth: MHB, Minimum inhibitory

\section{Referance}

1. Bullen J, Rogers HJ, Leigh L. Iron-binding proteins in milk and resistance to Escherichia coli infection in infants. $\mathrm{Br}$ Med J. 1972;1(5792):69-75. [DOI:10.1136/bmj.1.5792.69]

2. Hoshino A, Hisayasu S, Shimada T. Complete sequence analysis of rat transferrin and expression of transferrin but not lactoferrin in the digestive glands. Comparative Biochemistry and Physiology Part B: J. Biochem. Mol. Biol. 1996;113(3):491-7. [DOl:10.1016/0305-0491(95)02068-3]

3. Baker EN, Baker HM, Kidd RD. Lactoferrin and transferrin: functional variations on a common structural framework. Biochem. Cell Biol. 2002;80(1):27-34. [DOI:10.1139/o01-153]

4. Legrand D, Mazurier J. A critical review of the roles of host lactoferrin in immunity. Biometals. 2010;23(3):365-76. [DOI:10.1007/s10534-0109297-1]

5. Baker E, Baker H. Lactoferrin. Cell. Mol. Life Sci. 2005;62(22):2531. [DOI:10.1007/s00018-0055368-9]

6. Anderson BF, Baker HM, Norris GE, Rice DW, Baker EN. Structure of human lactoferrin: Crystallographic structure analysis and refinement at 2 - 8 Å resolution. J. Mol. Biol. 1989;209(4):71134. [DOI:10.1016/0022-2836(89)90602-5]

7. Moore SA, Anderson BF, Groom CR, Haridas M, Baker EN. Three-dimensional structure of diferric concentration: MIC, Minimum bactericidal concentration: MBC, Agar well diffusion assay: AWDA, Random Forest: RF, Support Vector Machines: SVM, Artificial Neural Network: ANN, Discriminant Analysis: DA.

\section{Acknowledgment}

I want to thank all those who have supported me in this work. It is worth mentioning that this essay is a thesis by Ms. Elnaz 's study at Islamic Azad University, branch of Sabzevar, Iran.

\section{Ethics Approval and Consent to Participate}

This article does not contain any studies with human participants or animals performed by any of the authors.

\section{Consent for Publication}

All authors gave their consent for publication.

\section{Conflict of Interest}

The authors declared no conflict of interest.

bovine lactoferrin at $2.8 \AA$ resolution. J. Mol. Biol. 1997;274(2):222-36. [DOI:10.1006/jmbi.1997.1386]

8. Karthikeyan S, Paramasivam M, Yadav S, Srinivasan A, Singh TP. Structure of buffalo lactoferrin at $2.5 \AA$ resolution using crystals grown at $303 \mathrm{~K}$ shows different orientations of the $\mathrm{N}$ and $\mathrm{C}$ lobes. Acta Crystallogr., Sect. D: Biol. Crystallogr. 1999;55(11):1805-13. [DOI:10.1107/S0907444999010951]

9. Sharma AK, Paramasivam M, Srinivasan A, Yadav $M$, Singh TP. Three-dimensional structure of mare diferric lactoferrin at $2.6 \AA$ resolution. J. Mol. Biol. 1999;289(2):303-17.

[DOI:10.1006/jmbi.1999.2767]

10. Khan JA, Kumar $P$, Paramasivam M, Yadav RS, Sahani MS, Sharma S, et al. Camel lactoferrin, a transferrin-cum-lactoferrin: crystal structure of camel apolactoferrin at $2.6 \AA$ resolution and structural basis of its dual role. J. Mol. Biol. 2001;309(3):751-61.

[DOI:10.1006/jmbi.2001.4692]

11. Conesa C, Sánchez L, Rota C, Pérez M-D, Calvo M, Farnaud $S$, et al. Isolation of lactoferrin from milk of different species: calorimetric and antimicrobial studies. Comparative Biochemistry and Physiology Part B: J. Biochem. Mol. Biol. 2008;150(1):131-9. [DOI:10.1016/j.cbpb.2008.02.005] 
12. Magjeed NA. Corrective effect of milk camel on some cancer biomarkers in blood of rats intoxicated with aflatoxin B1. J. Saudi Chem. Soc. 2005;9:253-63.

13. Agrawal RP, Saran S, Sharma P, Gupta RP, Kochar DK, Sahani MS. Effect of camel milk on residual $\beta$ cell function in recent onset type 1 diabetes. Diabetes Res. Clin. Pract. 2007;77(3):494-5. [DOI:10.1016/i.diabres.2007.01.012]

14. Quan S, Tsuda H, Miyamoto T. Angiotensin iconverting enzyme inhibitory peptides in skim milk fermented with lactobacillus helveticus 130b4 from camel milk in inner mongolia, china. J. Sci. Food Agric. 2008;88(15):2688-92. [DOI:10.1002/jsfa.3394]

15. Yen C-C, Shen C-J, Hsu W-H, Chang Y-H, Lin H-T, Chen $\mathrm{H}-\mathrm{L}$, et al. Lactoferrin: an iron-binding antimicrobial protein against Escherichia coli infection. Biometals. 2011;24(4):585-94. [DOI:10.1007/s10534-011-9423-8]

16. Kirkpatrick $\mathrm{CH}$, Green I, Rich RR, Schade AL. Inhibition of growth of Candida albicans by ironunsaturated lactoferrin: relation to host-defense mechanisms in chronic mucocutaneous candidiasis. J. Infect. Dis. 1971;124(6):539-44. [DOI:10.1093/infdis/124.6.539]

17. Arnold R, Brewer M, Gauthier J. Bactericidal activity of human lactoferrin: sensitivity of a variety of microorganisms. Infect. Immun. 1980;28(3):8938. [DOI:10.1128/iai.28.3.893-898.1980]

18. Clare D, Swaisgood H. Bioactive milk peptides: a prospectus. J. Dairy Sci.2000;83(6):1187-95. [DOI:10.3168/jds.S0022-0302(00)74983-6]

19. Mills S, Ross R, Hill C, Fitzgerald G, Stanton C. Milk intelligence: Mining milk for bioactive substances associated with human health. Int. Dairy J. 2011;21(6):377-401.

[DOI:10.1016/j.idairyj.2010.12.011]

20. Martin E, Ganz T, Lehrer RI. Defensins and other endogenous peptide antibiotics of vertebrates. J. Leukocyte Biol. 1995;58(2):128-36. [DOI:10.1002/ilb.58.2.128]

21. Wang Z, Wang G. APD: the antimicrobial peptide database. Nucleic Acids Res. 2004;32(suppl_1):D590-D2. [DOl:10.1093/nar/gkh025]

22. Yamauchi K, Tomita M, Giehl T, Ellison Rr. Antibacterial activity of lactoferrin and a pepsinderived lactoferrin peptide fragment. Infect. Immun. 1993;61(2):719-28. [DOI:10.1128/iai.61.2.719-728.1993]
23. Tomita M, Bellamy W, Takase M, Yamauchi K, Wakabayashi H, Kawase K. Potent antibacterial peptides generated by pepsin digestion of bovine lactoferrin. J J. Dairy Sci . 1991;74(12):4137-42. [DOI:10.3168/jds.S0022-0302(91)78608-6]

24. Bellamy W, Takase M, Yamauchi K, Wakabayashi H, Kawase K, Tomita M. Identification of the bactericidal domain of lactoferrin. BIOCHIM BIOPHYS ACTA PROTEIN STRUCT MOLEC ENZYM . 1992;1121(1-2):130-6. [DOI:10.1016/01674838(92)90346-F]

25. Farnaud S, Evans RW. Lactoferrin-a multifunctional protein with antimicrobial properties. Mol. Immunol. 2003;40(7):395-405. [DOI:10.1016/S0161-5890(03)00152-4]

26. Elbarbary HA, Abdou AM, Park EY, Nakamura Y, Mohamed HA, Sato K. Novel antibacterial lactoferrin peptides generated by rennet digestion and autofocusing technique. Int. Dairy J. 2010;20(9):646-51.

[DOI:10.1016/i.idairyj.2009.12.019]

27. Benkerroum N, Mekkaoui M, Bennani N, Hidane K. Antimicrobial activity of camel's milk against pathogenic strains of Escherichia coli and Listeria monocytogenes. Int. J. Dairy Technol. 2004;57(1):39-43. [DOI:10.1111/j.14710307.2004.00127.x]

28. El Sayed I, Ruppanner R, Ismail A, Champagne CP, Assaf R. Antibacterial and antiviral activity of camel milk protective proteins. J. Dairy Res. 1992;59(2):169-75. [DOI:10.1017/S0022029900030417]

29. Mehrin B, Saeid Z, Maryam I, Samane LA, Somaye $B$, Mahbobe $M$, et al. The Extract of Lactoperoxidase Enzyme from Camel Milk Using Chromatography Methods and Its Antibacterial Effects on Pseudomonas Aeruginosa". Clin. Biochem. 2011;13(44):S92. [DOI:10.1016/i.clinbiochem.2011.08.208]

30. Brouwer $\mathrm{CP}$, Rahman $\mathrm{M}$, Welling MM. Discovery and development of a synthetic peptide derived from lactoferrin for clinical use. Peptides. 2011;32(9):1953-63.

[DOI:10.1016/j.peptides.2011.07.017]

31. Agyei D, Tsopmo A, Udenigwe CC. Bioinformatics and peptidomics approaches to the discovery and analysis of food-derived bioactive peptides. Anal. Bioanal. Chem. 2018;410(15):3463-72. [DOI:10.1007/s00216-018-0974-1]

32. Dziuba B, Dziuba M. New milk protein-derived peptides with potential antimicrobial activity: An approach based on bioinformatic studies. Int. J. 
Mol. Sci. 2014;15(8):14531-45. [DOI:10.3390/ijms150814531]

33. Korhonen $\mathrm{H}$, Pihlanto A. Bioactive peptides: production and functionality. Int. Dairy J. 2006;16(9):945-60.

[DOl:10.1016/i.idairyj.2005.10.012]

34. Mizutani K, Toyoda M, Mikami B. X-ray structures of transferrins and related proteins. Biochim Biophys Acta. 2012;1820(3):203-11. [DOI:10.1016/j.bbagen.2011.08.003]

35. Dziuba M, Darewicz M. Food proteins as precursors of bioactive peptides-classification into families. Food Sci. Technol. Int. 2007;13(6):393-404. [DOI:10.1177/1082013208085933]

36. Dziuba J, Iwaniak A. Chapter 27 Database of Protein and Bioactive Peptide Sequences. Nutraceutical Sci. Technol. 2006;4:543. [DOI:10.1201/9781420028836.sec6]

37. Benkerroum N. Antimicrobial peptides generated from milk proteins: a survey and prospects for application in the food industry. A review. Int. J. Dairy Technol. 2010;63(3):320-38. [DOI:10.1111/j.1471-0307.2010.00584.x]

38. Agyei D, Danquah MK. Industrial-scale manufacturing of pharmaceutical-grade bioactive peptides. Biotechnol. Adv. 2011;29(3):272-7. [DOI:10.1016/i.biotechadv.2011.01.001]

39. Akalın AS. Dairy-derived antimicrobial peptides: Action mechanisms, pharmaceutical uses and production proposals. Trends Food Sci. Technol. 2014;36(2):79-95.

[DOI:10.1016/j.tifs.2014.01.002]

40. Minkiewicz P, Dziuba J, Iwaniak A, Dziuba M, Darewicz M. BIOPEP database and other programs for processing bioactive peptide sequences. J. AOAC Int. 2008;91(4):965-80. [DOI:10.1093/jaoac/91.4.965]

41. Thomas S, Karnik S, Barai RS, Jayaraman VK, IdiculaThomas S. CAMP: a useful resource for research on antimicrobial peptides. Nucleic Acids Res. 2009;38(suppl_1):D774-D80. [DOI:10.1093/nar/gkp1021]

42. Keil B. Proteolysis Data Bank: specificity of alphachymotrypsin from computation of protein cleavages. Protein Sequences Data Anal. 1987;1(1):13-20.

43. Wang G, Li X, Wang Z. APD2: the updated antimicrobial peptide database and its application in peptide design. Nucleic Acids Res. 2008;37(suppl_1):D933-D7. [DOI:10.1093/nar/gkn823]
44. Yang S, Huang H, Wang F, Aweya JJ, Zheng Z, Zhang $Y$. Prediction and characterization of a novel hemocyanin-derived antimicrobial peptide from shrimp Litopenaeus vannamei. Amino acids. 2018;50(8):995-1005. [DOI:10.1007/s00726-0182575-x]

45. Mosmann T. Rapid colorimetric assay for cellular growth and survival: application to proliferation and cytotoxicity assays. J. Immunol. Methods. 1983;65(1-2):55-63. 1759(83)90303-4]

[DOI:10.1016/0022-

46. Frija LM, Ntungwe E, Sitarek $P$, Andrade JM, Toma $M$, Śliwiński $T$, et al. In Vitro Assessment of Antimicrobial, Antioxidant, and Cytotoxic Properties of Saccharin-Tetrazolyl and-Thiadiazolyl Derivatives: The Simple Dependence of the $\mathrm{pH}$ Value on Antimicrobial Activity. Pharmaceuticals. 2019;12(4):167. [DOI:10.3390/ph12040167]

47. Balouiri M, Sadiki M, Ibnsouda SK. Methods for in vitro evaluating antimicrobial activity: A review. J. Pharm. Anal. 2016;6(2):71-9. [DOI:10.1016/i.jpha.2015.11.005]

48. Ciccaglione AF, Di Giulio M, Di Lodovico S, Di Campli E, Cellini L, Marzio L. Bovine lactoferrin enhances the efficacy of levofloxacin-based triple therapy as first-line treatment of Helicobacter pylori infection: an in vitro and in vivo study. J. Antimicrob. Chemother. 2019;74(4):1069-77. [DOI:10.1093/jac/dky510]

49. Nathan P, Law EJ, Murphy DF, MacMillan BG. A laboratory method for selection of topical antimicrobial agents to treat infected burn wounds. Burns. 1978;4(3):177-87. [DOI:10.1016/S0305-4179(78)80006-0]

50. Gasteiger E, Hoogland C, Gattiker A, Wilkins MR, Appel RD, Bairoch A. Protein identification and analysis tools on the ExPASy server. The proteomics protocols handbook: Springer; 2005. p. 571-607. [DOI:10.1385/1-59259-890-0:571]

51. Zasloff M. Antimicrobial peptides of multicellular organisms. nature. 2002;415(6870):389. [DOI:10.1038/415389a]

52. Hancock RE, Sahl H-G. Antimicrobial and hostdefense peptides as new anti-infective therapeutic strategies. Nat. Biotechnol. 2006;24(12):1551. [DOI:10.1038/nbt1267]

53. Wang G. Antimicrobial peptides: discovery, design and novel therapeutic strategies: Cabi; 2017. [DOl:10.1079/9781786390394.0000]

54. Shai Y. Mode of action of membrane active antimicrobial peptides. Peptide Science: Original 
Research on Biomolecules. 2002;66(4):236-48. [DOI:10.1002/bip.10260]

55. Zhang L, Rozek A, Hancock RE. Interaction of cationic antimicrobial peptides with model membranes. J. Biol. Chem. 2001;276(38):35714-22. [DOI:10.1074/ibc.M104925200]

56. Jenssen $H$, Hamill P, Hancock RE. Peptide antimicrobial agents. Clin. Microbiol. Rev. 2006;19(3):491-511. [DOI:10.1128/CMR.00056-05]

57. Wang G, Mishra B. The importance of amino acid composition in natural AMPs: an evolutional, structural, and functional perspective. Front. Immunol. 2012;3:221.

[DOI:10.3389/fimmu.2012.00221]

58. Conneely OM. Antiinflammatory activities of lactoferrin. J. Am. Coll. Nutr. 2001;20(sup5):389S95S. [DOI:10.1080/07315724.2001.10719173]

59. Utsugi T, Schroit AJ, Connor J, Bucana CD, Fidler IJ. Elevated expression of phosphatidylserine in the outer membrane leaflet of human tumor cells and recognition by activated human blood monocytes. Cancer Res. 1991;51(11):3062-6.

60. Orsi N. The antimicrobial activity of lactoferrin: current status and perspectives. Biometals. 2004;17(3):189-96.

[DOI:10.1023/B:BIOM.0000027691.86757.e2]

61. Wang J, Liu H, Zhao J, Gao H, Zhou L, Liu Z, et al. Antimicrobial and antioxidant activities of the root bark essential oil of Periploca sepium and its main component 2-hydroxy-4-methoxybenzaldehyde. Molecules. 2010;15(8):5807-17. [DOI:10.3390/molecules15085807]

62. Jahani S, Shakiba A, Jahani L. The Antimicrobial effect of lactoferrin on Gram-negative and Grampositive bacteria. Int. J. Infect. 2015;2(3). [DOI:10.17795/iji27594]

63. Drago-Serrano ME, De La Garza-Amaya M, Luna JS, Campos-Rodríguez R. Lactoferrinlipopolysaccharide (LPS) binding as key to antibacterial and antiendotoxic effects. Int. Immunopharmacol. 2012;12(1):1-9. [DOI:10.1016/i.intimp.2011.11.002] 


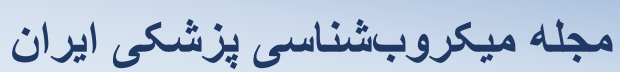

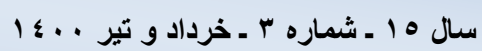 \\ Journal homepage: $w w w . i j m m . i r$}

شناسايى يك يِيتيد جديد بهدستآمده از لاكتوفرين جداشده از شير شتر با فعاليت بالقوه ضد ميكروبى

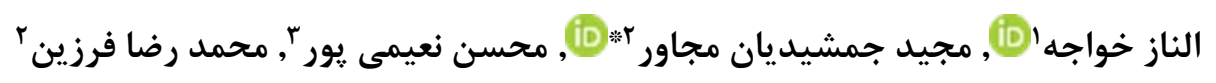

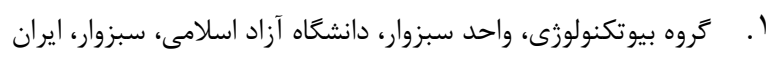

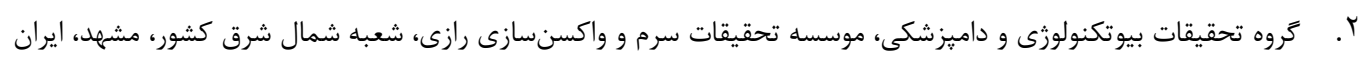

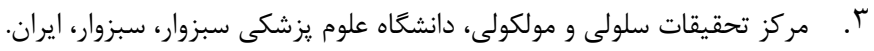

\begin{tabular}{|c|c|}
\hline "جكيله & اطلاعات مقاله \\
\hline 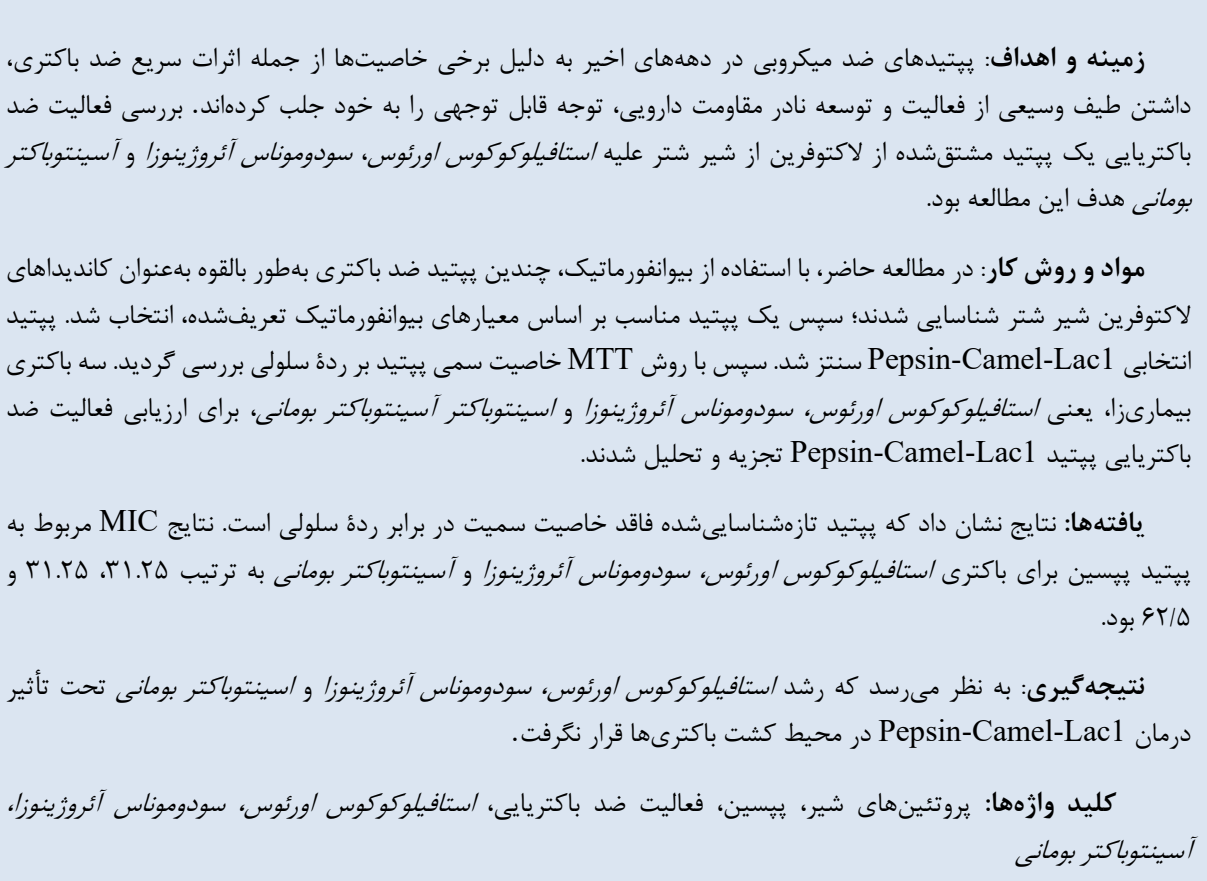 & 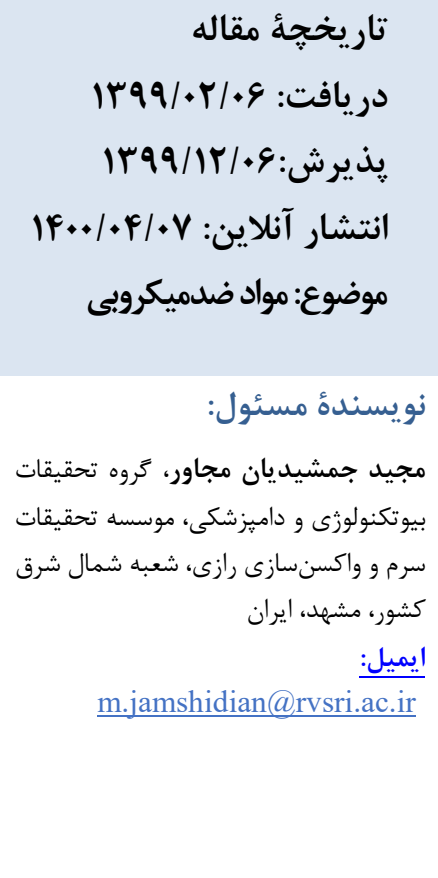 \\
\hline
\end{tabular}

